\title{
PRODUCTIVITY IMPROVEMENT IN THE UTILIZATION OF DOMESTIC AND IMPORTED INPUTS IN RESOURCE AND NON-RESOURCE- BASED INDUSTRIES: 1983-2005
}

\author{
NOORASIAH SULAIMAN \\ Faculty of Economics and Management \\ Universiti Kebangsaan Malaysia \\ ZAKARIAH ABDUL RASHID \\ KHALID ABDUL HAMID \\ Malaysian Institute of Economic Research
}

\begin{abstract}
The focus of the study is to examine the improvement in productivity on the utilization of intermediate input in resources and non resources-based industries of the Malaysian manufacturing sector. Since improvement in productivity can determine how well an input performed, our main interest rests on whether there exists any discrepancy between the performance of domestic and imported intermediate input. To undertake such an analysis, we employed various publications of the Malaysian Input-Output Tables. The input-output coefficients of domestic and imported inputs were then simulated by using the commodity technology model. It was anticipated that three main findings could be obtained from this study. Firstly, non resourcesbased industries have shown that both inputs have a higher improvement in productivity compared to resources-based industries. Secondly, this study revealed that resource-based industries have improved productivity relatively in the imported input used compared to domestic input. Thirdly, the number of industries that were efficient in utilizing imported input was higher, both, in resource and non resource-based industries. Results from this study show that imported intermediate input are still important in the production of manufactured products, even though many incentives have been given in order to increase the efficiency of the domestic input used.
\end{abstract}

Keywords: Productivity improvements, input utilization, resource and non resource-based industries. 


\section{Introduction}

Since the Malaysian independence in 1957, various economic policies especially on import substitution was undertaken with the intention to reduce the importation of goods which for the most part comprised of material inputs. As such, the Import Substitution Policy (1958-1967) was implemented in particular to reduce the importation of goods mostly comprising of consumer goods, which were produced by foreign companies in the country. The policy has been subsequently followed by Phase II of the Import Substitution Policy (1981-1985), emphasizing on the reduction of imported inputs used in the manufacturing sector (Alavi, 1996). The specific policy is exclusively undertaken to develop the local industry, especially the Small and Medium scale Industries (SMIs) as well as at the same time hand out incentives to foreign companies with the purpose to encourage raising the utilization of domestically produced inputs. In addition, the Investment Incentive Act (1986) gives away incentives to foreign companies that utilize domestic inputs in their production. In general, the combination of these efforts is hoped to increase deployment of domestic inputs in their chains of production.

Thus, in supporting efforts to enhance the utilization of domestic inputs, the Malaysian government in the course of the Sixth Malaysia Plan (1991-1995), has entrusted a new institution known as the Malaysian Industrial Development Authority (MIDA) to invigorate the manufacturing sector especially by the use of resource and non-resource-based industries (Malaysia, 1991). MIDA's industrial strategy served as a conduit that reduces dependence on imported material inputs and in turn encourages the use of domestic material inputs. Implicitly, it works as a strategy in promoting the production of domestic and exports, both local and foreign companies with a high content of domestic inputs. The use of domestic inputs by resource-based industries and non-resource-based industries is actually supported by several factors. Primarily, the most important factor is to increase the domestic value-added production in both resource and non-resource industries. Furthermore, these industries need to create intense linkage between economic sectors, especially the manufacturing and agricultural sectors. In addition, these efforts will create linkages between foreign and local industries, particularly SMIs, and finally, domestic inputs use can improve deficit in the current balance of payment at the most part by reduced dependency of imported inputs. 
Realising the above factors, the purpose of this paper is to examine the relative efficiency of domestic inputs and imported raw materials used in industries of the manufacturing sector, which is classified into resource and non-resource-based industries. Material inputs or sometimes referred to as intermediate material inputs are major ${ }^{1}$ sources of inputs in the Malaysian manufactures. In pursuance of this issue, one has to bear in mind that the utilization of domestic input is associated with resource-based industries and imported input with the non-resource based industries. The findings of this study show which industrial base utilized the inputs of domestic and imported efficiently. In addition, this study also seeks to analyse which subsector of the manufacturing sector, that is classified into resources and non-resource-based industries has more reliance on domestic input or imported raw materials between the periods of study.

Therefore, the purpose of this paper is to examine productivity improvement of domestic and imported inputs used among the subsectors of the manufacturing sector, which is classified into resource and non- resource-based industries. This study uncovered findings as to whether inputs were used productively or efficiently. In addition, this study also analysed which subsector of the manufacturing sector significantly utilized more inputs during the phase of the study.

This paper is stylized into six sections initially beginning with the introduction in section 1, followed by section 2 that discusses the related indicators of the manufacturing sector that supports the issue of the study as presented in section 1 . Section 3 offers the theoretical framework of the study. Section 4 outlines the model used in this study, data collection and input-output aggregation process. Section 5 presents the results of the study and discusses its findings. Finally, section 6 provides conclusions and some policy implications related to the study.

\section{Changes in Economic Structure}

As clearly highlighted in Table 1, the importance of the agricultural sector is shrinking in terms of its share from Gross Domestic Product (GDP) and exports. In contrast, the manufacturing sector has gained importance in terms of the average annual rate of growth, share in GDP and percentage of exports. It should be noted that within the agricultural sector, diversification had taken place thereby enabling a reduction in the traditional importance of rubber exports in the 1970s 
to palm oil, timber and cocoa in the 1980s and the 1990s. Similarly, the importance of tin in the mining sector had been replaced by the production of petroleum and gas. The share of manufacturing compared to export has increased since 1970. As of 2000 to 2005, its share had increased from $60.4 \%$ to more than $80.0 \%$. Amongst the manufacturing industries, the electrical and electronics sub-sector has a contribution of more than $70.0 \%$ of Malaysia's overall export (Malaysia, 2006).

Table 1

Changes in Economic Structure, 1970-2005

\begin{tabular}{|c|c|c|c|c|c|c|c|c|c|}
\hline \multirow{2}{*}{ Sector } & \multicolumn{4}{|c|}{ Average annual growth rate (\%) } & \multicolumn{5}{|c|}{ Share of GDP $(\%)$} \\
\hline & 1970-1979 & 1980-1989 & 1990-1999 & $2000-2005$ & 1970 & 1980 & 1990 & 2000 & 2005 \\
\hline Agriculture & 6.1 & 4.2 & 2.2 & 3.8 & 32.3 & 24.6 & 15.2 & 8.8 & 8.7 \\
\hline Mining & 8.6 & 5.9 & 8.5 & 2.3 & 5.8 & 4.6 & 11.8 & 10.9 & 15.2 \\
\hline Manufacturing & 16.0 & 8.8 & 12.1 & 4.2 & 12.3 & 19.2 & 24.2 & 32.6 & 30.5 \\
\hline Construction & 9.1 & 2.1 & 11.9 & 0.4 & 4.5 & 4.8 & 3.6 & 3.3 & 3.1 \\
\hline Services & 9.3 & 7.6 & 12.8 & 6.3 & 45.0 & 46.8 & 46.4 & 48.3 & 46.2 \\
\hline \multicolumn{10}{|c|}{ Share of exports (\%) } \\
\hline & 1970 & \multicolumn{2}{|c|}{1980} & 1990 & \multicolumn{2}{|c|}{2000} & \multicolumn{3}{|c|}{2005} \\
\hline Agriculture & 60.2 & \multicolumn{2}{|c|}{43.8} & 22.3 & \multicolumn{2}{|c|}{6.1} & \multicolumn{3}{|c|}{7.0} \\
\hline Mining & 26.4 & \multicolumn{2}{|c|}{34.3} & 17.8 & \multicolumn{2}{|c|}{7.2} & \multicolumn{3}{|c|}{9.8} \\
\hline Manufacturing & 12.2 & \multicolumn{2}{|c|}{21.1} & 59.3 & \multicolumn{2}{|c|}{85.2} & \multicolumn{3}{|c|}{80.5} \\
\hline Others & 1.2 & \multicolumn{2}{|c|}{0.8} & 0.6 & \multicolumn{2}{|c|}{1.5} & \multicolumn{3}{|c|}{2.7} \\
\hline
\end{tabular}

Source. DOS (2006): Statistics-Time Series 2005; Bank Negara Report, various years (share of export).

Note. Others include forestry.

\section{The Performance of Export and Import}

The role of foreign direct investment (FDI) has an undeniable marked importance in the context of the Malaysian economy. It had actually experienced substantial FDI inflows, especially in the manufacturing sector. They have unfortunately been declining in a later period, especially after China launched its world trade transition economy. Despite the above, the amount of FDI inflows in Malaysia is still higher compared to other ASEAN countries, with the exception of Singapore. The United Nations Conference Trade and Development reported that out of USD37.1 billion of FDI inflow into the South East Asian region, Malaysia had received USD3.9 billion in 2005 (UNCTAD, 2006). As most FDI are involved in non-resource-based industries, 
these industries contribute a high share of export of the manufactured goods. For this reason, these industries can also be categorized as export-oriented industries (see Appendix 1). As shown in Table 2, non-resource-based industries registered a figure of $79.4 \%$ to the manufacturing export, while resource-based industries exported only $13.9 \%$ in 2000. The share of export for non- resource-based industries was also high in 2005 , contributing $73.8 \%$. The high contribution to the manufacturing export implies that these industries are involved in export-oriented industries. As such, the electrical and electronics industry has only registered $65.7 \%$ of the manufacturing export in 1995 and increased to 72.5\% in year 2000 (Bank Negara, various years). The share of non-resource-based industries in contributing a high percentage in the export of manufactured goods may show a significant use of domestic and import based inputs.

For resource-based industries, since the majority of these sectors are domestic-oriented markets, some of them however, are also exportoriented industries, such as rubber, wood product, paper product and plastic product industries (see Appendix 2). Therefore, it is important to analyse the utilization of the domestic intermediate input, which shows that resource-based industries are expected to create a higher value added for the manufacturing products. For resource-based industries that are export-oriented market, these industries are able to maximize the output potential produced and a high use of the domestic input content in export may reduce a high deficit in current account balance.

Table 2

Share of Export in the Manufacturing Sector (\%)

\begin{tabular}{lcccc}
\hline Type of industries & 1981 & 1989 & 2000 & 2005 \\
\hline Resource-based industries & 25.1 & 17.9 & 13.9 & 18.0 \\
Non-resource-based industries & 74.9 & 82.1 & 79.4 & 73.8 \\
\hline
\end{tabular}

Source. Bank Negara Report (various years).

Table 3 shows that most of the intermediate goods imported are industrial supplies such as metal, fuel and lubricants, parts and accessories of capital goods (except transport equipment). These are amongst the intermediate goods required as parts of material input for the production of non-resource-based industries. The share of intermediate goods in the gross import has increased over a period of time from 1980 to 2000, which accounted for $45.5 \%$ and later increased 
to $73.8 \%$. In 2005 it decreased slightly to $71.0 \%$. The trend of reduction in the capital goods can be clearly seen in 2000 and 2005 which show plunging performances of import shares from $15.1 \%$ and $14.0 \%$ in both years respectively. Although the reduction of imported capital goods and imported consumption goods has decreased at a later period, it is most likely that a reduction in these two imported goods has been replaced by increasing high shares of imported intermediate goods. Bank Negara reported that heavy dependence on imported raw materials and machinery in these exports has resulted in an increase in the current account deficit by 5.9\% of the GDP in 1997. Substantially, as mentioned above most FDI concentrated on nonresource-based industries. This reflects one of the major problems in the development of the manufacturing sector, that is, a rather weak link forged with the domestic economy. The other major problem lies in the narrow industrial base with the export of manufactured goods concentrated in the electrical and electronics as well as the textile sectors.

Table 3

Share of Imported Goods, Real GDP Growth and Trade Indicators for Malaysia, 1980-2005 (\%)

\begin{tabular}{lrrrrrr}
\hline & 1980 & 1985 & 1990 & 1995 & 2000 & 2005 \\
\hline Capital goods $^{1}$ & 37.5 & 31.2 & 35.5 & 41.6 & 15.1 & 14.0 \\
Intermediate goods $^{2}$ & 45.5 & 46.8 & 41.5 & 40.8 & 73.8 & 71.0 \\
Consumption goods & 18.0 & 21.0 & 21.9 & 16.5 & 5.6 & 5.7 \\
Dual-use goods &.. &.. &.. &.. & 2.0 & 2.6 \\
Others &.. &.. &.. &.. & 1.5 & 1.7 \\
Import for re-exports & 2.0 & 0.7 & 1.1 & 1.1 & 2.0 & 5.0 \\
\hline Real GDP growth rate ${ }^{3}$ (\%) & 7.4 & -1.1 & 9.0 & 9.8 & 8.8 & 5.2 \\
\cline { 2 - 8 } & $1980-1989$ & $1990-1999$ & $2000-2005$ \\
Average real growth rate & \multicolumn{4}{c}{4.8} & \multicolumn{7}{c}{7.3} & \multicolumn{2}{c}{5.2} \\
\hline Trade balance (RM Million) & 5.2 & 8.9 & 7.1 & 0.2 & 79.1 & 125.6 \\
Current account balance (RM Million) & -0.6 & -1.7 & -2.5 & -18.7 & 32.0 & 75.7 \\
Current account (as \% of GDP) & -1.2 & -1.9 & -2.1 & -9.7 & 9.4 & 14.8 \\
Import (as \% of export) & 81.3 & 77.1 & 90.7 & 99.9 & 78.8 & 76.7 \\
\hline
\end{tabular}

Source. Share of imported goods are obtained from Bank Negara Report (various Years); real GDP growth and trade indicators are obtained from DOS (2006): Malaysia statistics-time series, 2005.

Note.

${ }^{1}$ capital goods [capital goods (except transport equipment), industry equipment and transport equipment];

2 intermediate goods (food and beverage mainly for industry, industrial supplies, metal, fuel and lubricants, parts and accessories of capital goods (except transport equipment).

3 real GDP growth: 1980-1985: 1978=100; 1990-2005:1987=100. 
Unrestrained and high importation of raw materials for the chains of production in non-resource-based industries can exert pressure on a country's current account. In fact, deficit in current accounts has been a major concern particularly since imported raw material creates huge leakages and heavy financial burden in terms of acquiring machines, parts and technology. Although trade account balance was surpluses from 1985 to 2005, Malaysia experienced a continuous deficit in its current account balance from 1985 to 1995 (see Table 3). The surplus in the current account balance is only exhibited in a later period 1998. Moreover, the current account deficit has increased $-2.1 \%$ in 1990 to $-9.7 \%$ in 1995 . Total import as a percentage of total export had recorded above $75.0 \%$ over the period of 1980 to 2005, where the highest amount of total import as a percentage of total export accounted for $99.9 \%$ in 1995 . The events of import and export increased parallel to export. Since the manufactured goods contributed a large amount of Malaysia's export, export of the manufacturing sector may reflect a high content of imported raw materials. As shown in Figure 1 and Figure 2, only two subsectors of the resource-based industries indicated an imported input which used more than 50\%, while four subsectors were observed in the non-resource-based industries. These are the subsectors of chemicals and other chemical products for resource-based, and the subsectors of basic metal products, nonelectrical machinery, electrical machinery and motor vehicles for nonresource-based industries.

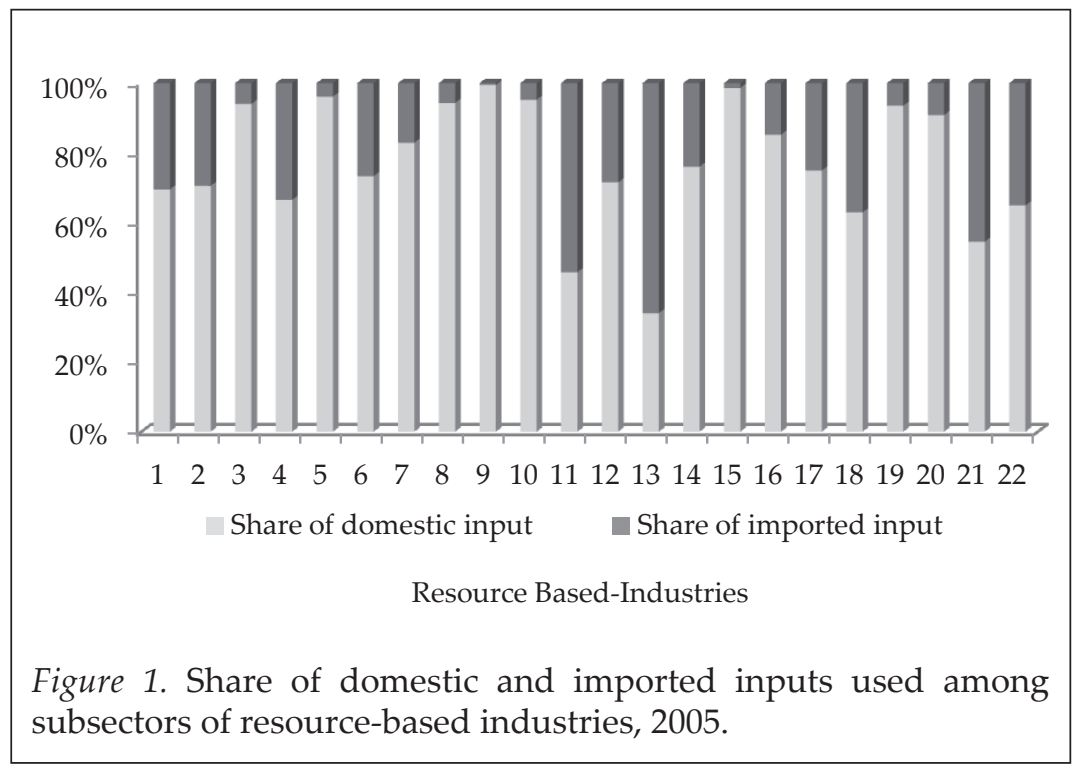


The total average shows that resource-based industries registered more than $60.0 \%$ of the share of the domestic input and less than $40.0 \%$ of the imported input, except in 1991. In contrast, non-resource-based industries have shown less than $50.0 \%$ of the domestic input and more than $50.0 \%$ of the imported input used (see Appendix 2). This implies that resource-based industries are actually sourced by domestic inputs, while non-resource-based industries rely on the imported input and the FDI in Malaysia concentrated on non-resource-based industries.

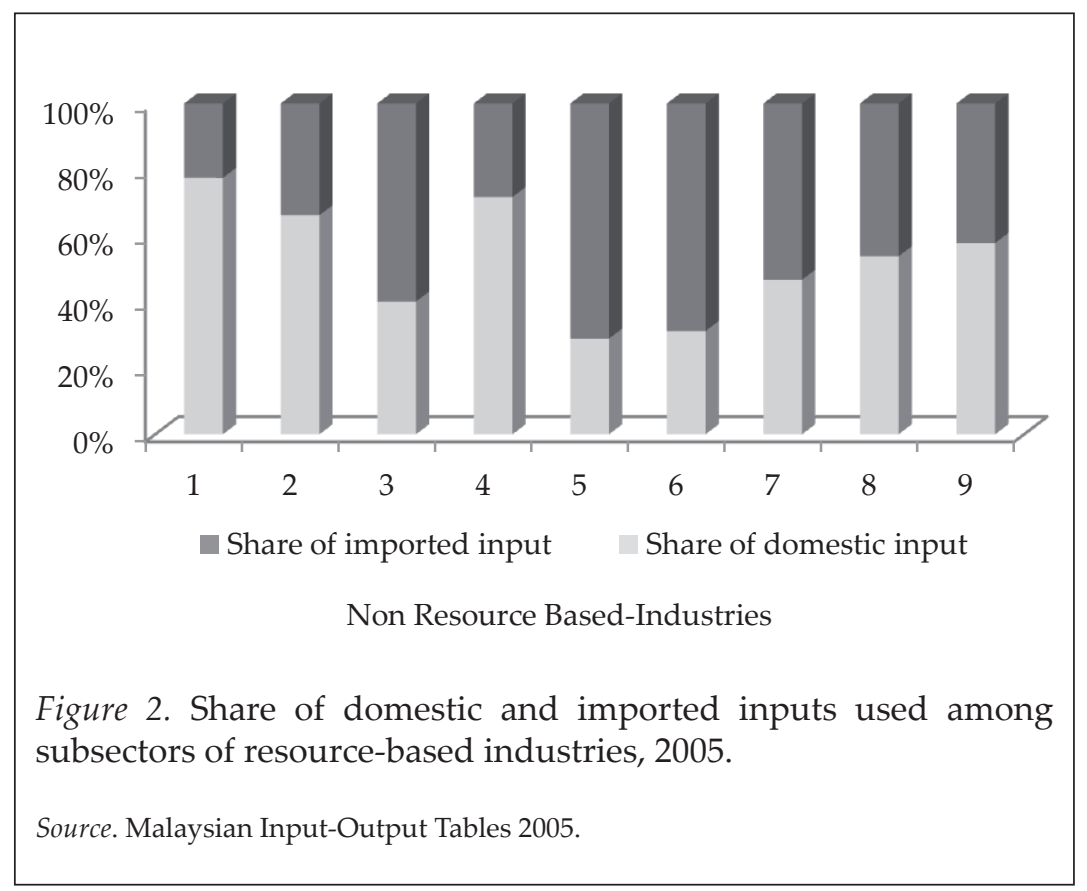

\section{Theoretical Framework}

The above relative efficiency appraisal relates to the testing of the new growth theory especially by proponents who were once popularly headed by Kaldor. He analysed the factor of production from the viewpoint of how resources contribute towards output in the economy. Kaldor debated that in many areas manufacturing industries work faster than agriculture as assumed in the embodiment theory that both the physical and non-physical elements work in combination to the increase in output. In the productivity theory, the efficiency of 
the factor of production is related to the concept of efficiency. While productivity is the amount of output produced relative to the amount of resources used, efficiency is the value of output relative to the costs of inputs used. A change in price of inputs might lead a firm to change the mix of input used, in order to reduce costs of input used, and improve efficiency, without actually increasing the quantity of output relative to the quantity of inputs. A change in technology, however, might allow the firm to increase output with a given quantity of inputs; such an increase in productivity would be more technically efficient, but might not reflect any change in efficiency in terms of allocation.

\section{The Input-Output Model}

In this study, the computations of the technical coefficient are adopted from the Commodity Technology Model (CTM). Unlike other conventional models, is the well-known one proposed by Leontief (1953). The model uses a single table of the input-output matrices. The transaction table ${ }^{2}$ in the conventional model presumes that commodities and sectors are classified in the same way. Thus, the technical coefficient of the model is called the direct technical coefficient,

$$
A=\left[\frac{x_{i j}}{x_{j}}\right](i, j=1,2,3, \ldots n)
$$

where $x_{i j}=$ inputs from sector $i$ to produce outputs in sector $i$;

$x_{j}=$ total inputs of sector $j$ which is equal to the total outputs in the $j$ throw of the input-output table.

By using the CTM model, this model employs the basic table of the input-output matrices, which provides a compatible procedure with a modern input-output table. The uses of basic tables separated into two subtables consist of the 'supply' and 'use' tables (SUT), which have been suggested by many authors (Raa \& Kop Jansen, 1990; Viet, 1986). The model suggests that sectors have a multitude of inputs to produce an output. Therefore, the separate table of input and output matrices that already exist in the SUT need not be forced into the single matrix, meaning that the multiplication of 'use' and 'make' matrix will result in a symmetric table. Therefore, SUT can be used 
directly in the analysis of input-output (Raa, 2004). Moreover, it is preferable to have raw 'use' and 'make' matrices separate without purified or otherwise manipulated industries.

The technical coefficients, $A_{c^{\prime}}$ of CTM, employs 'supply' and 'use' tables (SUT), as presented in equation (ii).

$$
\begin{aligned}
& A_{c}=[u, v] \\
& \text { where } u \text { denotes 'use' table and, } \\
& v \text { denotes 'supply' table. }
\end{aligned}
$$

The 'use' table is also known as the input matrix, which shows the consumption of intermediate input by industries and the 'supply' table is known as the output or 'make' matrix ${ }^{3}$. In the system of National Accounts, the 'use' table matrix records the inputs used by industries, where $u_{i j}$ shows the total input of commodity $i$ consumed by industry $j$. The 'make' matrix records primary and secondary products produced by each industry, where $u_{i j}$ shows the total output of industry $i$ producing commodity $j$. In other words, commodity $j$ is produced by industry, $i$ (Raa and Wolff, 1991).

$$
\text { where } \begin{aligned}
u_{i j} & =\text { is a }(m \times n) \text { matrix } \quad(i, j=1,2,3, \ldots, n) \\
v_{i j} & =\text { is a }(m \times n) \text { matrix } \quad(i, j=1,2,3, \ldots, n)
\end{aligned}
$$

From equation (ii), we can get equation (iii) as: $u=A v^{t}$

If the 'use' table matrices represent dimension products by industry and the 'make' table highlights dimension industries by products matrices, then $v^{t}$ (transposed) would have dimension products by industry. The input-output coefficient, postulate proportionality between inputs collected from the 'use' table, while the output collected from the 'supply' table needs to be transposed. In solving equation (iii) in the matrix operation, we obtain the technical coefficient derived from CTM (Raa, 2004) as:

$$
A_{c}=u\left[v^{t}\right]^{-1}
$$

where $t$ and -1 resents the combined operations of transposition and inversion of the indicated matrix, and;

c denotes commodity technology model. 
By employing CTM, a best selection from all the models in the computation of technical coefficients, fulfils all axioms of the inputoutput analysis (Raa, 2004). The choice of the model is made on the basis of reasonable assumptions. This model has an assumption that each commodity has a unique input structure, irrespective of the sector of fabrication. The number of activities must equal the number of commodities. This model also assumes that each commodity is produced by the same technology, irrespective of the production of industry. In this case, industries are considered an independent combination of output in sector $j$ and each with their separate input coefficients.

In this study, $U$ matrix, which is referred to input matrices are classified into two. These are domestic input matrices, $\left(U_{d}\right)$ and imported input matrices, $\left(U_{m}\right)$. Changes in input coefficients for each input, domestic and imported input, can be presented as in equation (v).

Change in input coefficients: $A_{c i j}=\frac{a_{c i j_{t 1}}-a_{c i j_{t 0}}}{a_{c i j_{t 0}}}$ where $A_{c i j}=$ change in input coefficients;

$a_{c i j}=$ input coefficients from sector $i$ to sector $j$ or the intermediate inputs of the $i$ th sector used by the $j^{\text {th }}$ sector, $(i, j=1,2,3, \ldots, n)$;

$t_{1}$ and $t_{0}=$ the terminal year and the initial year.

Equation (3) estimates changes of domestic and imported inputs used to produce one unit of output relative to the time, which is referred to the sub-periods of the study. Both changes in domestic and imported input used can measure efficiency of the respective input used to produce one unit value of output. This shows the requirements of the input from sector $i$ used in sector $j$ in order to produce one ringgit value of output, $j$. Therefore, from column-wise of the matrix, $A$, presents the amount of input required to produce one unit value of output in Malaysian ringgit. The input coefficient also reflects unit cost per ringgit of output. The results of the change in input coefficients are expected to be both in terms of positive and negative signs. In general, a negative sign shows an improvement in productivity of the input used. This also means that the input is utilized efficiently. On the other hand, the positive sign presents a contrasting sign of the input coefficients, revealing deterioration of productivity. Furthermore, change in input coefficients both for domestic and imported input is weighted by output to obtain weighted average of proportionate change in input coefficient of each sub-period of the study. 
Weighted average of proportionate change: $\frac{d A_{c j} \times d Q_{j}}{\sum d Q_{j}}$
where $d \mathrm{Q}_{j}=$ total output of industry, $j$; and,

$\sum d \mathrm{Q}_{j}=$ grand total output of industry, $j$.

\section{Data Sources and Input-Output Aggregations}

This study employs data from the Malaysian I-O Tables for 1983, 1987, 1991, 2000 and 2005 published by the Department of Statistics, Malaysia. This study is classified into sub-periods of 1983-87, 1987-91, 91-2000 and 2000-05. The basic table of the Malaysian I-O is utilized, which includes the basic table of domestic input, imported input and output matrices. The basic table of imported input is obtained from the differences between the basic table of the total input and the basic table of domestic input matrices.

The existing framework of national account has governed the potential maximum size of the Malaysia I-O tables. However, due to the scopes of this study that only focuses on the manufacturing sector, this study has reduced the I-O tables into 32 by 32 industries/commodities. This encompasses all 31 industries of the manufacturing sector and a 'single' sector is representing 'other sectors' which includes services, agriculture, mining and construction, and the rest of the public sectors.

\section{Results and Discussion}

Based on the classification in Appendix 1, resource-based industries comprise of 22 subsectors of the manufacturing sector, while nonresources-based industries consist of 9 subsectors. In this study, the results of productivity improved to produce one unit value of output measures efficiency in the input used both for domestic and imported inputs. As shown in Table 4, for non-resources-based industries, it was found that productivity improved relatively higher compared to resources-based industries when using domestic intermediate input which is indicated by $40.1 \%$ and $35.5 \%$ during the sub-periods $1983-$ 87 and 1987-1991, respectively. The result is similar in the case of imported intermediate input use, which is non-resource based which also indicated a high percentage of productivity improvement. These are at the amounts of $50.4 \%, 25.3 \%$ and $367 \%$ during the sub-periods 1983-1987, 1987-1991 and 1991-2000, respectively. 
For resource-based industries, this study revealed that the productivity improved relatively higher for imported input compared to domestic input used. This accounts for $22.6 \%$ and $19.5 \%$ during the sub-periods of 1983-1987 and 1991-2000. For the sub-period of 1987-1991, these industries registered a lower percentage of productivity improvement, which was only $0.7 \%$ for domestic input used and $-14.7 \%$ for imported input. The lower percentage of improvement during this sub-period is due to the emerging economy from the 1985 recession. The recovery of the economy can be seen from the percentage increase in the productivity improvement both in the domestic and imported input used in the sub-period of 91-2000.

During the sub-period of 2000-2005, resource-based industries indicated $12.9 \%$, while non-resources- based industries accounted for $12.7 \%$ of productivity improvement in domestic input use. The finding shows that the resource-based industries have a lower productivity improvement in domestic input use among the subsectors. In contrast, the number of subsectors in resource-based industries is actually larger than the subsectors of non-resource-based industries. For imported input, both industries have shown that the percentage decreased to $2.7 \%$ and $2.4 \%$ respectively for resource and non-resource-based industries. This was lower due to the global economic slow-down during the period 2000 until 2005, and the use of imported input in resource-based industries dropped from $38.4 \%$ to $22.0 \%$ (see Appendix 2).

In terms of total input, non-resource-based industries indicated $46.1 \%, 32.9 \%$ and $30.0 \%$ during the sub-periods of $1983-1987$, 1987-1991 and 1991-2000, respectively. Resource-based industries indicated $13.0 \%, 8.0 \%$ and $14.3 \%$, respectively. These are relatively lower than non-resource-based industries. The lower percentage for resources-based industries highlights that these industries still have room for improvement especially in terms of domestic input use. The improvement of domestic input will increase the value-added of the domestic input content. Meanwhile, local industry produces less wastage in domestic resources and will also reduce dependency on non-resource-based industries when using domestic input. However, for the sub-period of 2000-2005, the percentage of productivity improved in imported input use by only $4.3 \%$ for non-resource-based industries and $6.7 \%$ for resource-based industries. 
IJMS 19 (1), 87-114 (2012)

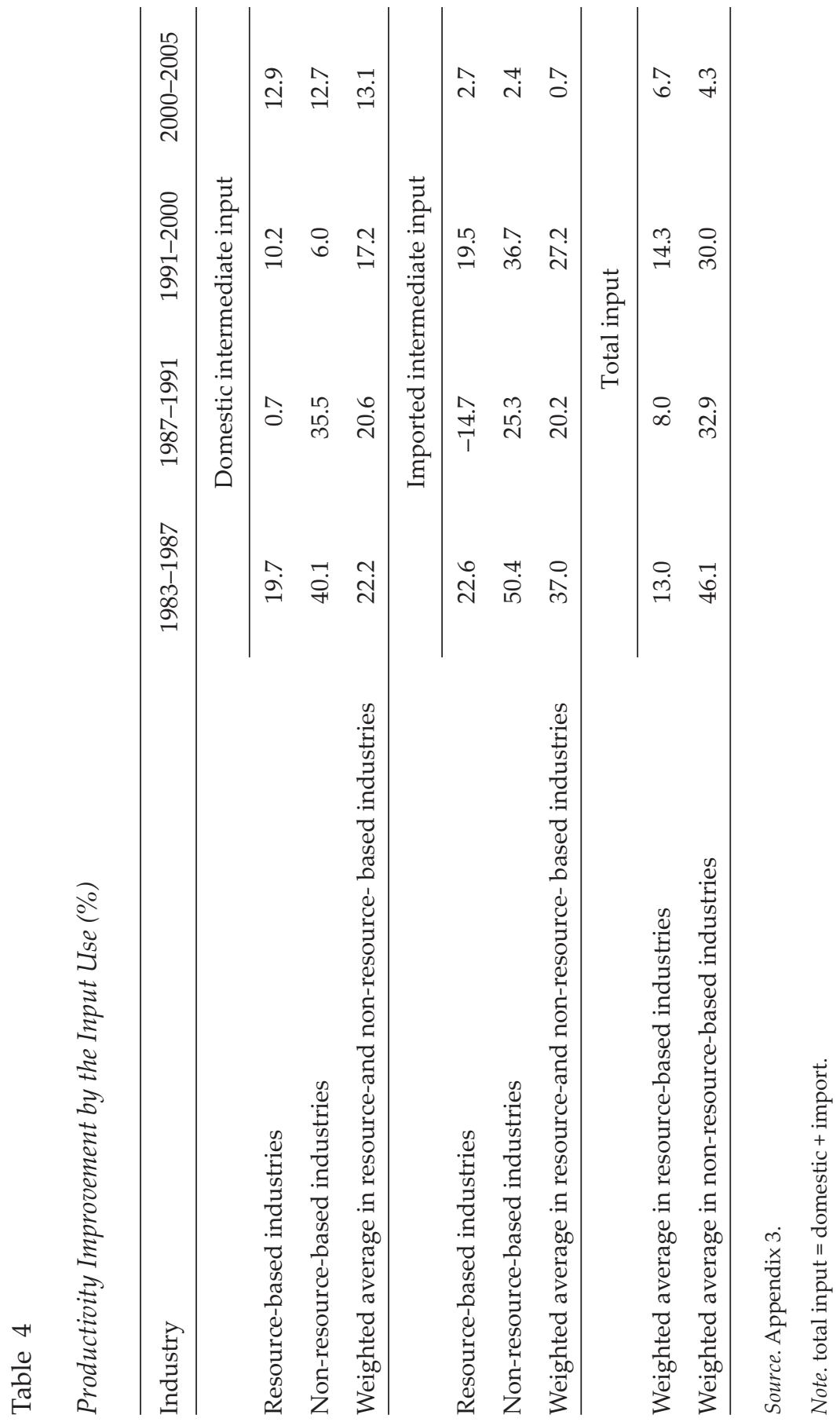


Productivity improvement for both the domestic and imported input can be related to a larger contribution that the intermediate input is the major component of growth in TFP for the manufacturing sector. This implies that the growth in TFP of the manufacturing sector is dependent on input growth. In other words, growth in TFP is actually led by the 'input driven' economy. This might be true as other studies found that the miracle of the East Asian economy may be characterized by the 'input-led' growth (Krugman, 1994; Young, 1994b; Kim \& Lau, 1994). These studies revealed that the Korean economy catchup process with the industrial nations in its late industrialization has been predominantly input-led growth. Past studies on growth with respect to Malaysia also conclude that the input growth, particularly intermediate input, makes a larger contribution to the output growth (Okamoto, 1994; Maisom, Mohd Ariff \& Nor Aini, 1993; Tham, 1996; 1997; Noriyoshi, Nor Aini, Zainon, Rauzah \& Mazlina, 2002).

The larger contribution of intermediate input to growth in manufacturing output was also obtained in several other studies. Tham (1996) found that, in general, the average value shares of intermediate input in the Malaysian manufacturing output growth between 1986 and 1990 were the highest among all the inputs. Tsao (1985) also found the same results for Singapore between 1970 and 1979, where the average value shares of intermediate input in the output growth were the highest among all inputs. Similarly, Nishimizu and Robinson (1984) also indicated the same results for Japan between 1955 and 1973, Korea (1960-1977), Turkey (1963-1976) and Yugoslavia (1965-1978). In the same way, Gan, Wong and Tok (1993) study on the Singaporean manufacturing sector yielded a similar result, in which the major source of growth of output between 1986 and 1990 was the growth in material input. Moreover, in all these studies, input growth has contributed relatively more to output growth.

Table 5 shows the number of subsectors efficient in domestic and imported input used amongst industries of resource-and-non resource-based industries over four sub-periods of the study. Nonresource-based industries show that the percentages of the subsectors with had relatively improved productivity in domestic input used accounted for $70.0 \%, 80.0 \%, 40.0 \%$ and $88.9 \%$, while imported input accounted for $80.0 \%, 60.0 \%, 80.0 \%$ and $11.1 \%$, respectively. The findings show that non-resource-based industries are rather efficient in using both domestic and imported input during the study, except for the imported input in 2000-2005. 
In the case of resource-based industries, imported input indicated that about $85.7 \%$ of the subsectors improved, respectively for the subperiods of 1983-1987 and 1991-2000. The results show that the number of subsectors improved in imported input use is relatively larger than the others, even though the share of imported input use indicates less than $40.0 \%$ of the total input ${ }^{4}$ (see Appendix 2). The percentage of subsectors that improved in domestic input use accounted for $38.1 \%$, $52.4 \%$ and $47.6 \%$ during the sub-periods of 1983-1987, 1987-1991 and 1991-2000, respectively. During the three sub-periods, this study implies that the percentage of subsectors improved in domestic input use is relatively low, even though the average share of domestic input use among the subsectors is relatively high with more than $60 \%$ of the total input. However, the percentage increased to $81.8 \%$ for the subperiod of 2000-2005. The improvement in productivity in domestic input use can be seen in processed rubber, rubber products, furniture and fixture, other chemical products and plastic products industry (see Appendix 3). The increase in the percentage of subsectors improvement in domestic input use implies that domestic input has gained improvement in productivity. The domestic input has received priority among the manufacturers resource-based industry in terms of utilization.

A previous study found that resource-based industries were more export-oriented compared to the non- resource-based industries during the period 1975-1994. In addition, almost 70 per cent of the manufacturing industries were highly dependent on imported input and almost of all these industries were non-resource-based (Alavi, 1999). The result also revealed that there was a positive relationship between export share and imported input content for the nonresource-based industries. In contrast, the relationship was negative for the resource-based industries. Surprisingly, the findings show that domestic-oriented industries were generally more highly dependent on imported inputs compared to the export-oriented industries.

The following figures, from Figures 3 to 5 exhibit subsectors of resource-and non-resource-based industries in domestic and imported input use improved in productivity if located in the lower side of the horizontal line. For the sub-period 1983-1987, most subsectors of resource-based industries were relatively in the position of the improvement area, while this occurred for resource-based industries in terms of imported input use. The resources-based industries have relatively improved in domestic input use during the sub-period of 1987-1991. This can also be seen in non-resources-based industries for imported input use. The improvement in domestic input use for the period 1987-1991 may be due to the economic recession in 1985. 
IJMS 19 (1), 87-114 (2012)

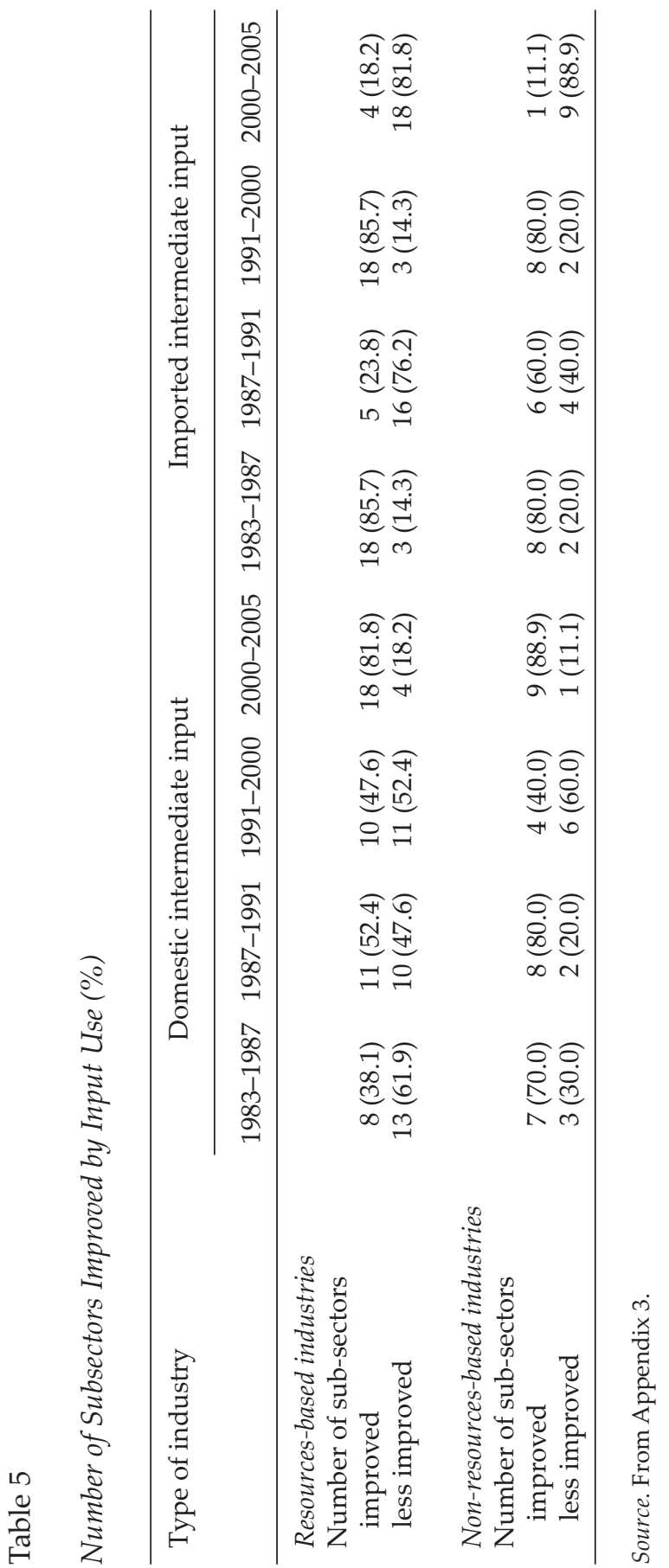


For the sub-period of 1991-2000, both industries have shown that imported input use relatively improved than domestic ones, which is similar to the first sub-period of the study. On the other hand, both industries have experienced domestic input use that relatively improved compared to imported input during the sub-period of 2000-2005. The substantial progress shows that domestic input is used efficiently in both industries, though the content of imported input has remained at $40.0 \%$ for resource-based and $50.0 \%$ for nonresource-based industries. These are contributed by a majority of the subsectors in the resources-based indutries, except beverages, wood products, paper and printing, and paint and lacquers industries. A similar contribution can be seen in most industries of non-resourcebased industries, except textiles (see Appendix 3).

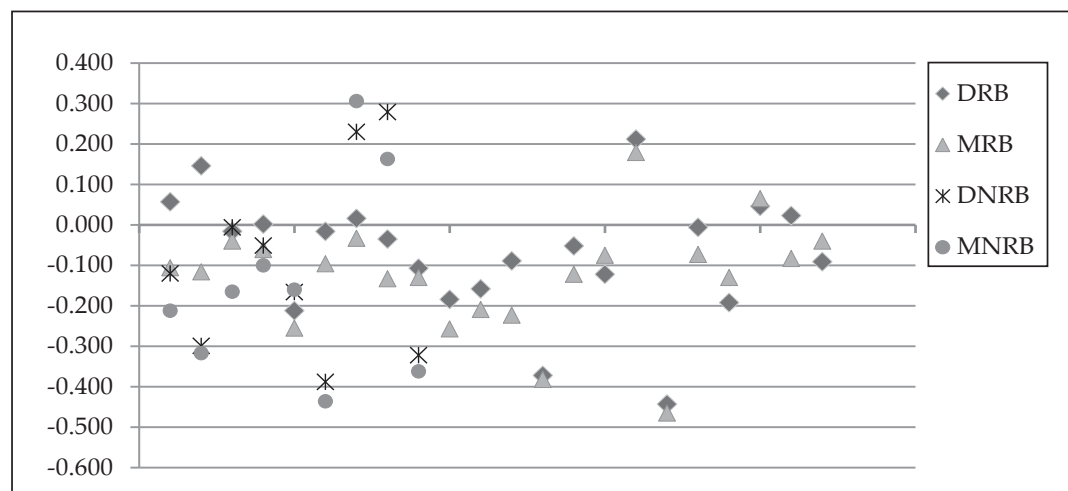

Figure 3. Distribution of subsectors in resource and non-resourcebased industries in domestic and imported input used, 1983-1987.

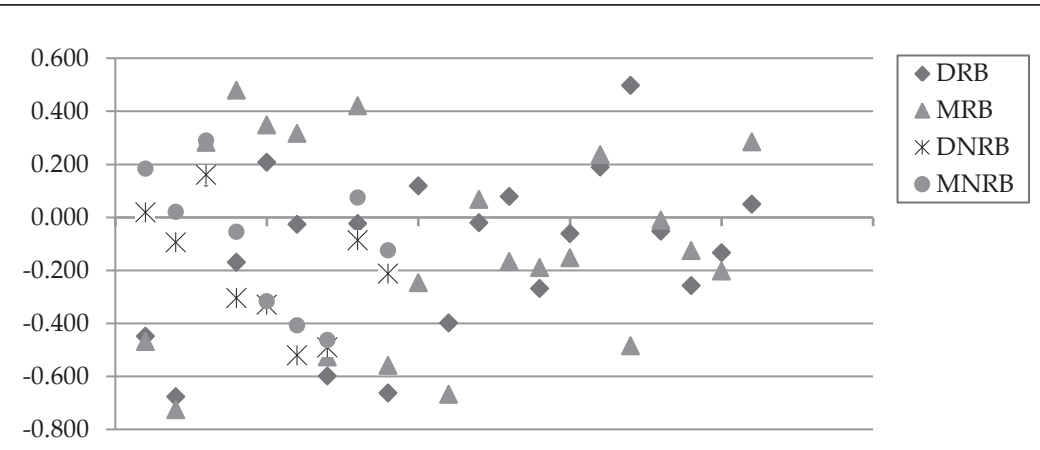

Figure 4. Distribution of subsectors in resource and non-resourcebased industries in domestic and imported input used, 1987-1991. 


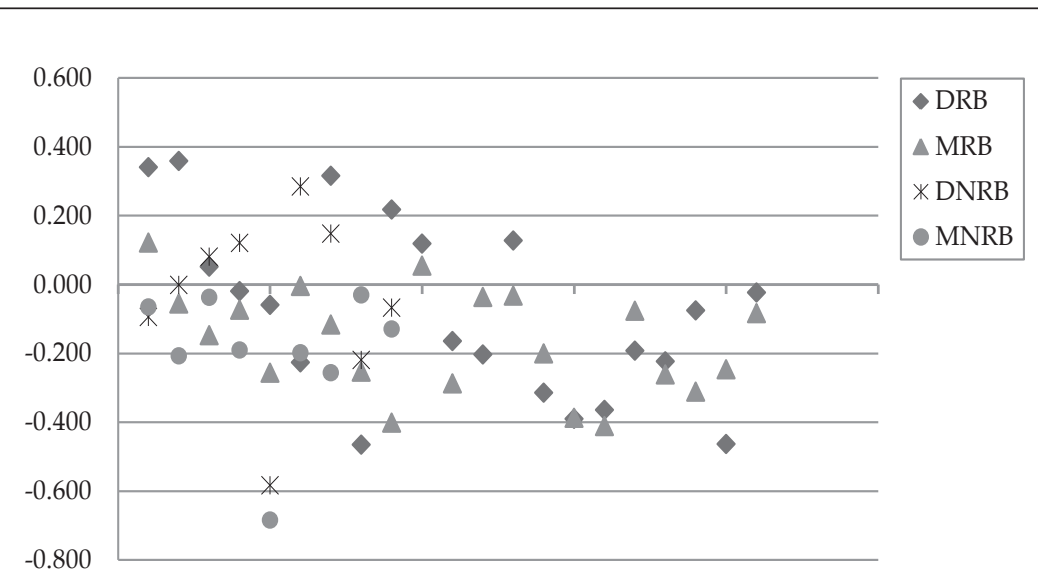

Figure 5. Distribution of subsectors in resource and non-resourcebased industries in domestic and imported input used, 1991-2000.

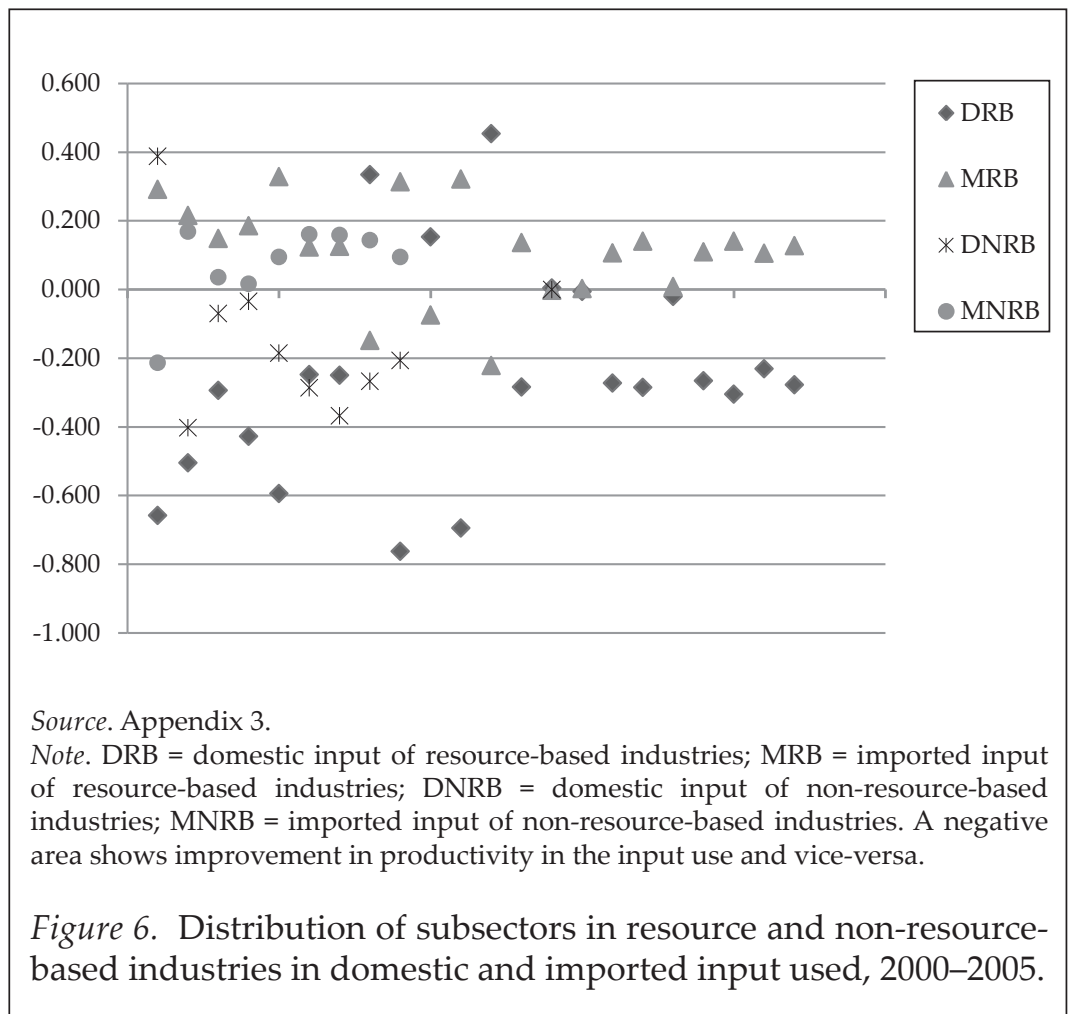




\section{Conclusion and Policy Implications}

Based on the study, there are three main findings that need to be highlighted in this paper. Firstly, this study concludes that, nonresources-based industries have shown a higher percentage of subsector improvement in using domestic and imported intermediate inputs. Secondly, for resources-based industries, it shows a high percentage of productivity improvement in the imported input use, while domestic input use is rather low during the first three sub-periods of the study. This actually reflects that resource-based industries are relatively less efficient in using domestic inputs compared to imported input use. Resource-based industries have shown productivity improvement in imported input use, but not for domestic input. Thirdly, the number of industries that improved in using imported input is higher, both, in resources-and non-resourcesbased industries. This indicates that both resource-and non- resourcebased industries have used imported input more productively. Meanwhile, resources-based industries do not show the use of domestic input efficiently.

The three main results of this study indicate that, firstly, non resourcesbased industries rely substantially on imported raw materials. Heavy reliance on the imported raw materials will have an adverse effect on the country's Balance of Payments. As reported by the Annual Report of Bank Negara (2005), imported raw materials constituted $20 \%$ of the total raw materials utilized in resource-based industries while in nonresources-based industries it can be as much as $60 \%$. Most leading firms of the non-resource-based industries are actually multinational companies of FDI. Thus, there is no surprise that these leading firms of non-resource-based industries of electronics and electrical machinery have particularly a high content of imported raw materials, as high as $70 \%$. It is also interesting to note that the share of our economy's total export by non-resource-based industries is phenomenal (more than $70.0 \%$ ) compared to that of resource-based industries hovering less than 20.0\% (Bank Negara, 2006). The over dependence on imported raw materials is normally a characteristic of multinational companies operating in the host countries, engaging in processing industries which import unfinished components and export finished products (Tsao, 1985). This results in weak linkages between indigenous industries and foreign companies, In contrast, linkages within the multinationals' network of plants located throughout the world tend to be stronger. 
Secondly, the number of subsectors relatively efficient in resourcebased industries in terms of domestic input use is smaller than imported input over the period of the study, and it shows an increase in a later period of the study. At the same time, non-resource-based industries have also shown an increasing trend in terms of the number of subsectors relatively efficient in using domestic input. In contrast, both resource-and non-resource-based industries have shown a higher number of subsectors, which is relatively efficient in using imported inputs. The local sources of domestic input may be due to resourcebased industries which did not use domestic input as productively as imported input, thereby leading to the probable underutilization of domestic input and non-resource-based industries which are highly dependent on imported input.

Thirdly, in resource-and non-resource-based industries, imported raw materials are used more efficiently than domestic raw materials, in terms of the number of industries efficient over the period of the study. On the other hand, in resource-based industries domestic raw materials are not used efficiently as well as imported raw materials. It is interesting to note that although resource-based industries sourced their material inputs domestically, the Malaysian manufacturers utilize their minor material inputs more efficiently than their major ones. The production of the manufacturing sector implies that Malaysian manufacturers did not utilize domestic input in efficient ways due to having substantial sources of local input. In contrast, multinational companies have shown efficiency in both domestic and imported input use in their production.

\section{End Notes}

1. Zainal Aznam Yusof and Phang (1994) demonstrated that the largest component of cost in the Malaysian manufacturing sector was the cost of raw materials.

2. Transaction table refers to the table of intermediate inputs.

3. 'Use' matrix refers to the use of commodities by the producing industry, and the 'make' matrix shows the quantities of each commodity made by each industry.'

4. $\quad$ See Appendix 2 for more details of domestic and imported input use in resources and non-resources-based industries. 


\section{References}

Alavi, R. (1996). Industrialization in Malaysia: Import substitution and infant industry in Malaysia. London: Routledge.

Alavi, R. (1999). Export expansion and imported input intensity in the Malaysian manufacturing sector. IIUM Journal of Economics and Management, 7(2), 17-50.

Bank Negara (2005 \& 2006). Bank Negara Annual Report. Ministry of Finance, Malaysia.

Bank Negara (various years). Bank Negara Annual Report. Ministry of Finance, Malaysia: Kuala Lumpur.

Department of Statistics. (2006). Malaysia economic statistics-time series 2005. Kuala Lumpur: Putrajaya.

Department of Statistics. (various years). Malaysian Input-output tables. Putrajaya, Kuala Lumpur.

Department of Statistics. (various years). Industrial manufacturing survey. Putrajaya, Kuala Lumpur.

Gan, W. B., Wong, F. C., \& Tok, Y. W. (1993). Total factor productivity in the Singapore manufacturing sector during the 1980s (Unpublished mimeo).

Kim, Jong-II, \& Lawrence, J. L. (1994). The sources of economic growth of the East Asian newly industrialized countries. Journal of the Japanese and International Economies, 8(3), 235-271.

Krugman, P. R. (1994). The myth of Asia's miracle. Foreign Affairs, 73(6), 62-77.

Leontief, W. (1953). Structural change. In Leontief, W. et al. (Eds.), Studies in the structure of the American Economy (pp. 17-52). New York: Oxford University Press.

Maisom Abdullah, Mohd. Ariff, H., \& Nor Aini, Mohd. Amdzah (1993). Productivity and efficiency in Malaysian manufacturing sector: A time series analysis. In Proceeding of the First Malaysian Econometric Conference (Ed.) M. Semundram \& M. Yap. Malaysian Institute of Economic Research (MIER): Kuala Lumpur.

Malaysia. (2006). The Ninth Malaysia Plan 2001-2005. Kuala Lumpur: National Printing Department.

Nishimizu, M., \& Robinson, S. (1984). Trade policies and productivity change in semi-industrialized countries. Journal of Development Economics, 16(1-2), 177-206.

Noriyoshi, O., Nor Aini, M. A., Zainon, B., Rauzah, Z. A. \& Mazlina S. (2002). Productivity of foreign and domestic firms in the Malaysian manufacturing industry. Asian Economic Journal, 16(3), 215-228. 
Okamoto, Y. (1994). Impact of trade and FDI liberalization policies on the Malaysian economy. The Developing Economies, 32(4), $460-478$.

Raa, T. T. (2004). Structural economics. London: Routledge.

Raa, T. T., \& Kop Jansen, P. (1990). The choice of model in the construction of input-output coefficients matrices. International Economic Review, 31(1), 213-227.

Raa, T. T., \& Wolff, E. N. (1991). Secondary products and the measurement of productivity growth. Regional Science and Urban Economics, 21(4), 581-615.

Tham, S. Y. (1996). Productivity, growth and development in Malaysia. The Singapore Economic Review, 40(1), 41-63.

Tham, S. Y. (1997). Determinants of productivity growth in the Malaysian manufacturing sector. ASEAN Economic Bulletin, 13(3), 333-343.

Tsao, Y. (1985). Growth without productivity: Singaporean manufacturing the 1970s. Journal of Development Economics, 18, 25-38.

UNCTAD. (2006). World Investment Report 2006. FDI from developing and transition economies: Implications for development. Geneva: United Nations.

Viet, V. Q. (1986). Study of input-output tables: 1970-1980. Geneva: United Nations.

Young, A. (1994b) Lessons from the East Asian NICs: A contrarian view. European Economic Review, 38(3-4), 964-973. 
IJMS 19 (1), 87-114 (2012)

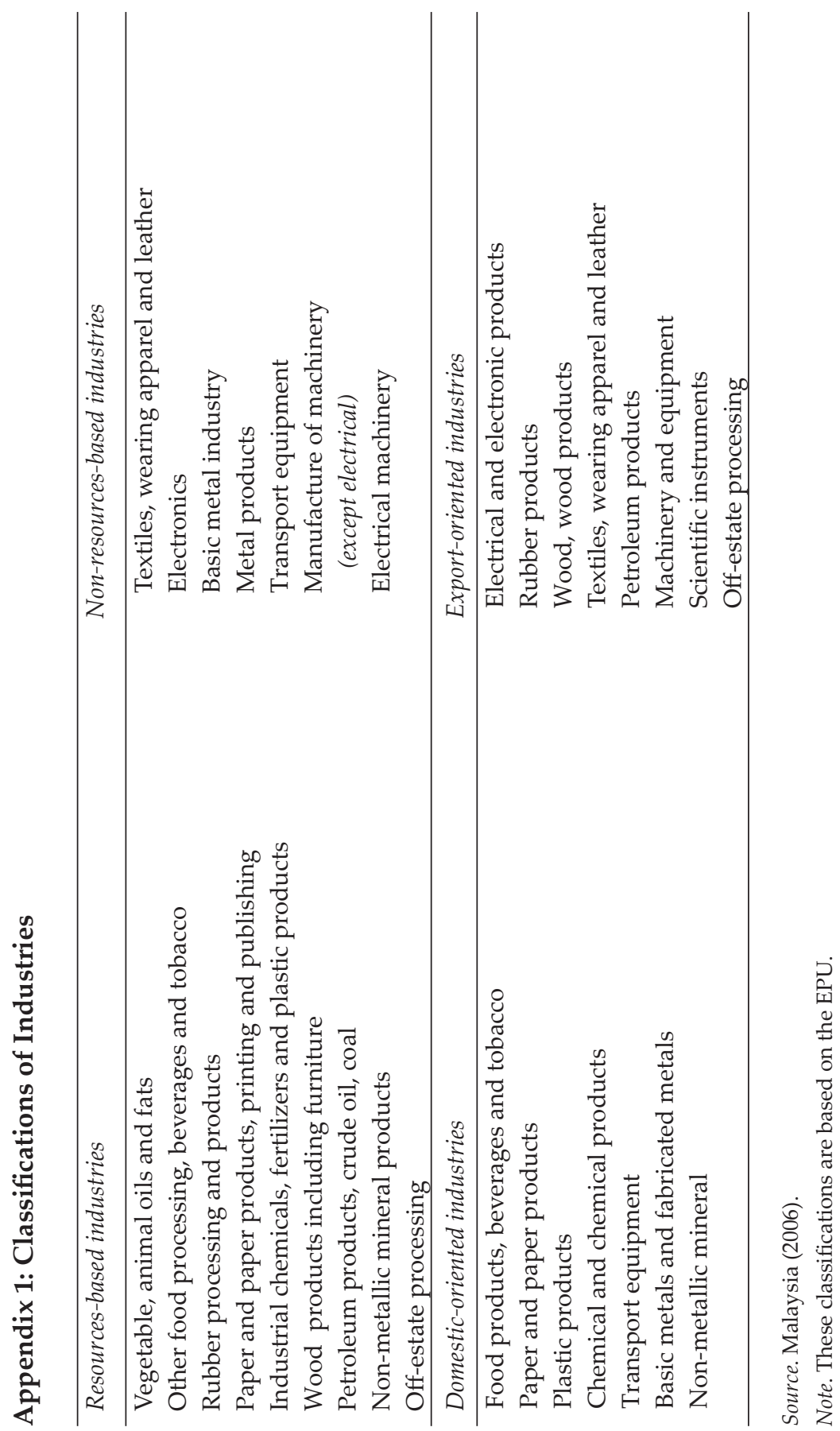




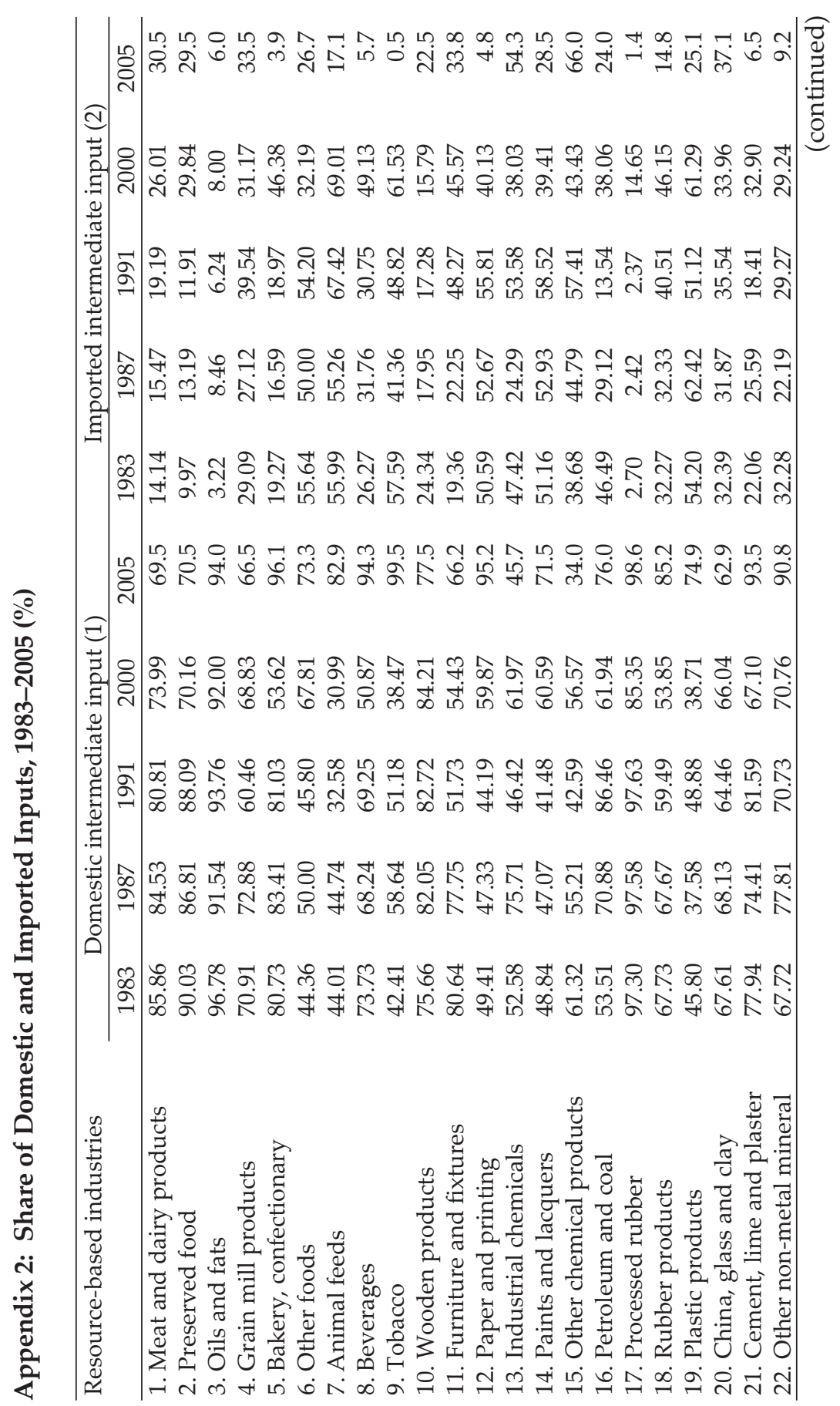


IJMS 19 (1), 87-114 (2012)

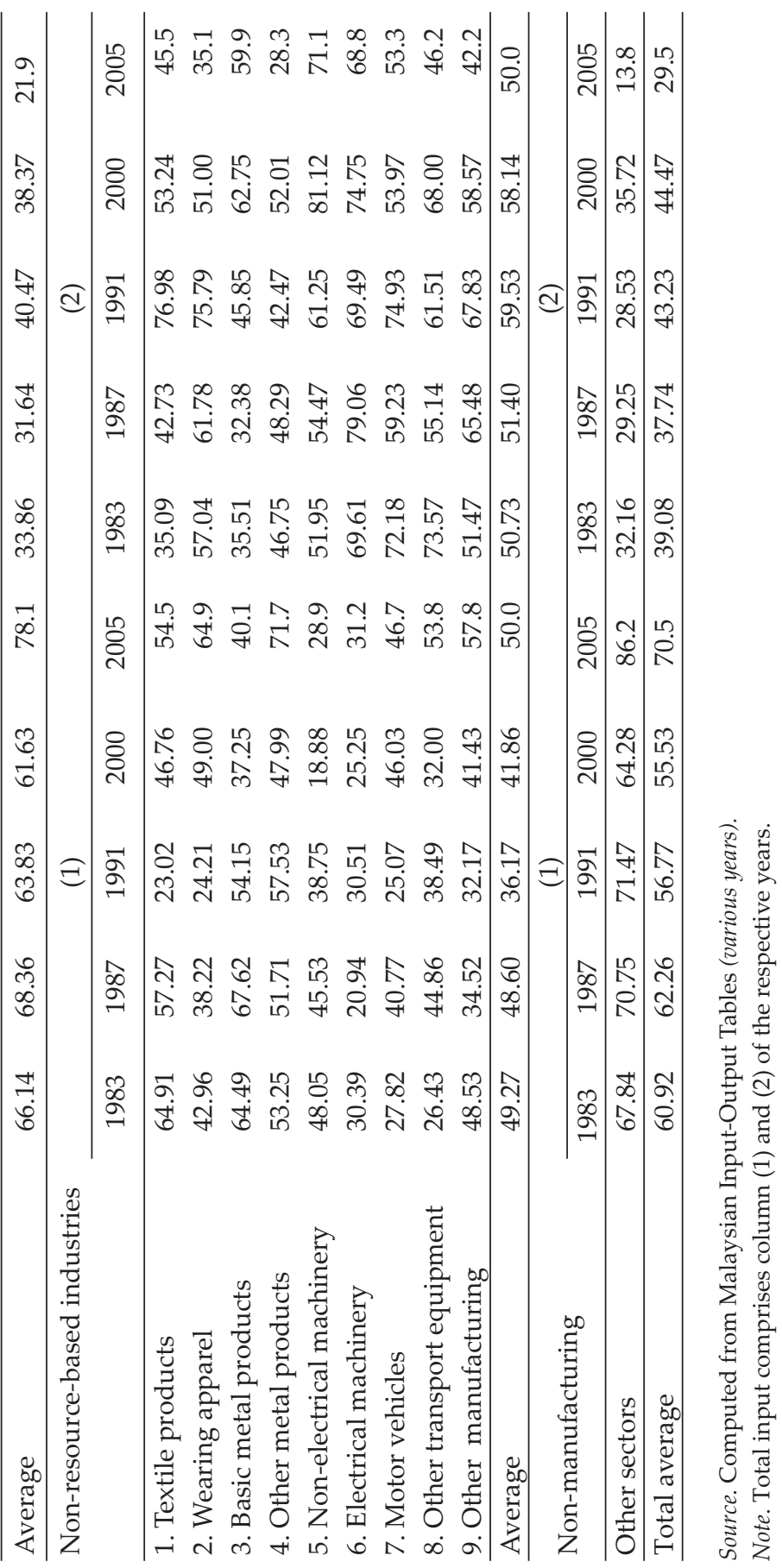




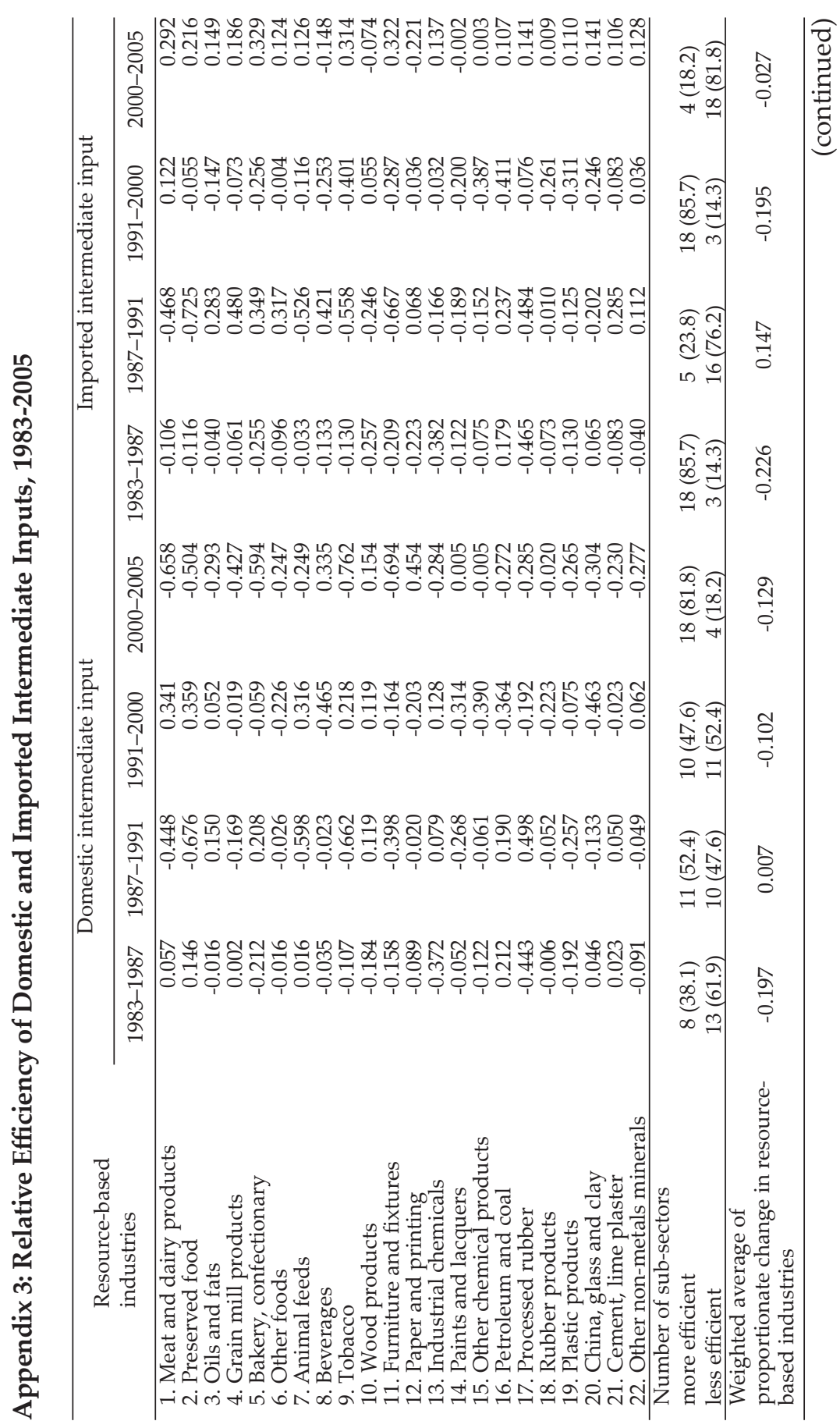


IJMS 19 (1), 87-114 (2012)

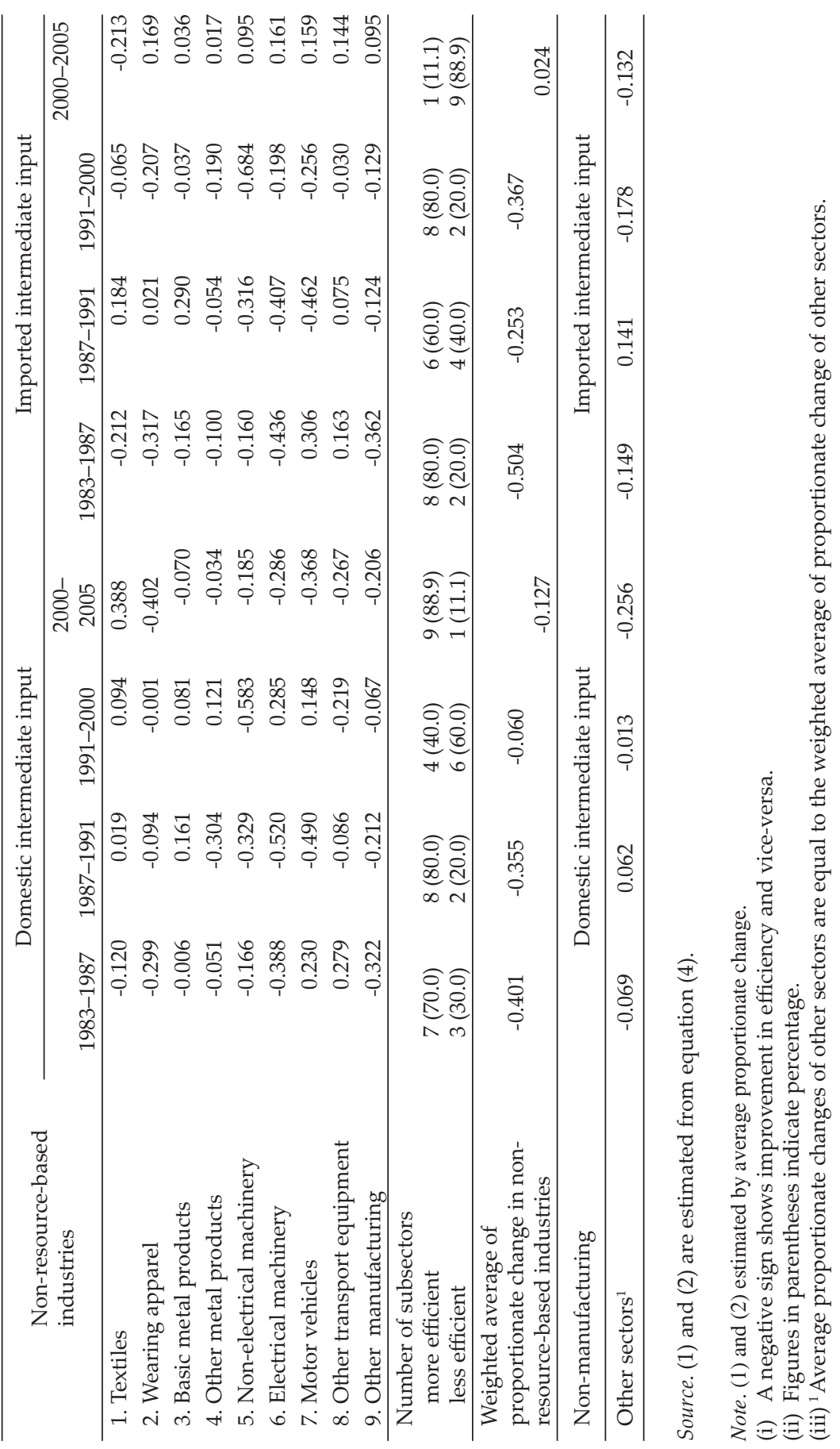

